\title{
Simulating upland rice yield at diverse temperatures using DSSAT4.7-CERES-Rice crop model under changing climatic conditions
}

\author{
Shams Shaila Islam ${ }^{1^{*}}$ and Ahmed Khairul Hasan ${ }^{2}$ \\ ${ }^{1}$ Department of Agronomy, Faculty of Agriculture, Hajee Mohammad Danesh Science and Technology University, \\ Dinajpur- 5200, Bangladesh. \\ ${ }^{2}$ Department of Agronomy, Faculty of Agriculture, Bangladesh Agricultural University, Mymensing-2202, Bangladesh.
}

\section{Article history:}

Received: 4 Jan., 2021

Revised: 16 April, 2021

Accepted: 3 May, 2021

\section{Citation:}

Islam SS and AK Hasan. 2021. Simulating upland rice yield at diverse temperatures using DSSAT4.7-CERES-Rice crop model under changing climatic conditions. Journal of Cereal Research 13(1): 62-69. http://doi. org/10.25174/2582-2675/2021/109954

\section{"Corresponding author:}

E-mail: shaila.hmdstu@gmail.com

(C) Society for Advancement of Wheat and Barley Research

\begin{abstract}
Declaration of climate emergency reminds that the main source of variations in worldwide food production sourced from developing countries and is of utmost concern. Process-based models use simplified functions to express the interactions between upland rice growth and the major environmental factors (i.e., climate, soils, and management) that affect crops yield. This research was conducted to investigate the DSSAT-CERES-Rice model for simulating the impact of different temperature $\left(28^{\circ} \mathrm{C}, 30^{\circ} \mathrm{C}\right.$ and $\left.32^{\circ} \mathrm{C}\right)$ on upland grain yield (Dawk Payawm, Mai Tahk, Bow Leb Nahng, Dawk Kha 50 and Dawk Kahm). The results showed that the temperature significantly affected the grain yield, flowering, and maturity date. The highest grain yield bearing genotype was Bow leb Nahng $\left(6235.80 \mathrm{kgha}^{-1}\right)$ with the highest variation between the genotypes. At maximum temperature $32^{\circ} \mathrm{C}$ simulated grain yield varied from (3194-6669) $\mathrm{kgha}^{-1}$, at high temperature $30^{\circ} \mathrm{C}$ it varied from $3252-6667 \mathrm{kgha}^{-1}$ while at moderate temperature $28^{\circ} \mathrm{C}$ 3189-6711 $\mathrm{kgha}^{-1}$ was the observed range. However, results indicated that moderate temperature i.e., $28^{\circ} \mathrm{C}$ gave the highest simulated grain yield. Thus, it was demonstrated that the CERES-Rice model was more useful as a tool for simulating grain yield under the changing different temperature conditions.
\end{abstract}

Key words:DSSAT; CERES-Rice model; temperature effect; upland rice; grain yield; phenological traits

\section{Introduction}

Model simulation, one of the important tools in agriculture. It has increased the utility of parameters related to meteorological, soil and plant aspects to predict the crop yield and growth features (Lone et al., 2016). Upland rice (Oryza sativa L.) is an essential cereal crop nourishing more than half of the world's population and contributing 50 to $80 \%$ of regular caloric consumption (FAO, 2019; Nayak et al., 2019). Upland rice suffers severely from irregular environmental factors, e.g., air temperature, drought, and precipitation (Jalota et al., 2009). As rice originated in tropical or subtropical areas and is a low-temperature sensitive crop. Rice crop growth and development are severely damaged below $15^{\circ} \mathrm{C}$. But extreme temperatures are also destructive to plant growth. High temperature causes heat stress and ultimately negatively affects the rice crop yield (Cruz et al., 2007). At different times during the life cycle, rice plant is differentially sensitive to temperature stress. Hence, the critically low and high temperatures, normally below $20^{\circ} \mathrm{C}$ and above $30^{\circ} \mathrm{C}$ vary from one growth stage to another (P. Krishnan et al., 2011). It has been observed that the mean temperature, temperature sum, range, distribution pattern and diurnal changes or a 
combination of these, are highly correlated with grain yields and had significant issues (Araus et al., 2011).

According to the Intergovernmental Panel on Climate Change (IPCC, 2013) the increase in global mean surface temperatures for 1986-2005 and 2081-2100 are in the range of $0.3^{\circ} \mathrm{C}$ to $4.8^{\circ} \mathrm{C}$. Similar changes are also expected in Thailand, where the average day temperature increase is likely to be $2.0^{\circ} \mathrm{C}$ to $4.0^{\circ} \mathrm{C}$ by 2100 (IPCC, 2013). The simulation impacts of climate change reveal that rice production is expected to decrease by 4.56 to $33.77 \%$ in response to the future climate scenarios for 2030 to 2090 in Thailand reported by Tazhibayeva et al., (2009). Thus, assessment of relation between variability in climate changing and yield help in decision making regarding the management of agricultural crops (Abbas et al., 2017).

Several crop models have been used for a long time to assist in crop management practices and in exploring physiological mechanisms under different environments (Reidsma et al., 2010). DSSAT (Decision Support System for Agrotechnology Transfer) is a software combining of several dynamic crop simulation models, and with the help of soil, daily weather (historical or future), and management data it can predict accurately growth, development, and yield of crops to assist farmers in developing long-term plans (Lizaso et al., 2011). CERES (Crop Environment Resource Synthesis)-Rice model in DSSAT software has adjustments for different temperatures, and it can be used to evaluate the risks for upland rice production system (Soler et al., 2007). This study focused to simulate the effect of temperatures on yield performance for phenology, grain yield, tops weight, leaf area index, harvest index, and tillers number. The DSSAT-CERES-Rice model simulated upland rice yield, above ground biomass and growth durations at harvest and the valued were compared with the observed valued during calibration processes. Climate change induced global warming is a serious threat to the prevailing rice production systems in Thailand. Therefore, an attempt was made to predict the upland rice yield under different temperature regimes by simulating different temperature changes on yield contributing characters using the DSSAT v 4.7 CERES simulation model.

\section{Materials and methods}

\subsection{Experimental plant materials}

For simulating the crop growth and yield of upland rice field experiments were conducted from July to December in 2017-2018 at the research area of Plant Sciences Department, Faculty of Natural Resources, Prince of Songkla University, Hat Yai campus $\left(7.13^{\circ} \mathrm{N}, 100.26^{\circ} \mathrm{E}\right.$ and 63 meters), Thailand. For this purpose, five popular upland rice genotypes namely, Dawk Pa-yawm, Mai Tahk, Bow Leb Nahng, Dawk Kha 50 and Dawk Kahm were selected. The experiments were conducted as a split plot using Complete Block Design (CRD) with three replications. The main plots were five Thai upland rice genotypes and sub plots with three temperatures $\left(28^{\circ} \mathrm{C}\right.$, $30^{\circ} \mathrm{C}$ and $32^{\circ} \mathrm{C}$ ) which were set up after one month of planting date up to harvesting by using the data logger (UA-002-08 HOBO Pendant, for Temp/Light) and daily solar radiation $\left(\mathrm{MJm}^{-2}\right.$ day $\left.^{-1}\right)$ was calculated by using weatherman tools in DSSAT v4.7 simulation model.

Each treatment consisted of five rows ( 5 meters/row) with five genotypes, which were randomized and replicated within each block. Each genotype was planted $30 \mathrm{~cm}$ apart between rows and $25 \mathrm{~cm}$ within the rows. N-P-K was applied at the rate of $15 \mathrm{kgs}$ of $\mathrm{N}, \mathrm{P}$ and $\mathrm{K} / \mathrm{ha}$ as urea, super phosphate, and muriate of potash to the plots before planting. Nitrogen was applied in four equal splits at basal, active tillering, panicle initiation and flowering stages to the individual replication as per the treatment schedule of fertilizer application. Agronomic operations e.g., weed and insect control were done manually. Insect pests were controlled by the application of $20 \mathrm{ml}$ per $1 \mathrm{~L}$ Cypermethrin 10\% w/v EC and $50 \mathrm{ml}$ per $1 \mathrm{~L}$ Benfuracarb $20 \% \mathrm{w} / \mathrm{v}$ EC with water. At 30 days after planting, urea fertilizer (46-0-0) was applied.

\subsection{Set up of temperature treatments $\left(28^{\circ} \mathrm{C}, 30^{\circ} \mathrm{C}\right.$ and $32^{\circ} \mathrm{C}$ )}

Three temperature treatments including weather parameters, maximum and minimum temperatures with air intensity, were recorded by using a data logger (UA-002-08 HOBO Pendant, for Temp/Light), that was set up after one month from planting of the experiments and daily solar radiation $\left(\mathrm{MJm}^{-2}\right.$ day $\left.^{-1}\right)$ was calculated by using weatherman tools in DSSAT V4.7. Moreover, Dawk Pa-yawm genotype was used as border crop to avoid the varietal errors.

To run the DSSAT-CERES-Rice model, the following four input files were created. 


\section{Daily weather data}

Maximum and minimum air temperatures, rainfall, and solar radiation (derived from sunshine hour data) were collected from the weather station of Kho Hong Agrometeorological office, Hat Yai, Thailand for the 2017/2018 cropping season.

\section{Soil data}

For generating the data on soil characteristics soil samples from 0-5, 5-15,15-25, 25-35, 35-50 and 50-65 cm depths were taken before planting. Soil class, organic carbon $(\%)$, sand, silt, clay (\%), soil texture, soil $\mathrm{pH}$ in water, field capacity (\%), cation exchange capacity, total nitrogen, potassium and phosphorus, potential root distribution and depth were recorded as per Wilkens et al., 2004.

\section{Agronomic traits data}

Sowing date, emergence date, flowering date, physiological maturity date, panicle initiation (when $50 \%$ and $100 \%$ of the crop had reached those stages) plant population, plant height, tiller number, tops weight (grain weight), harvest index and grain yield/genotype/production.

\section{Genetic cultivar coefficients file}

The following genetic coefficients parameters [P1 (Time period or basic vegetative phase), P2O (Critical photoperiod), P2R (Photoperiodism coefficients), P5 (Grain filling duration coefficient), G1 (Spikelet number coefficient), G2 (Single grain weight), G3 (Tillering coefficients) and G4 (Temperature tolerance coefficient)] were calibrated and validated by Lone et al., (2019) for same location were used to carry the simulation studies.

\subsection{Statistical analysis}

The analysis of variance (ANOVA) was performed by R/ agricolae program (Mendiburu and Simon 2007). Mean separation was done by Least Square Difference (LSD) for split plot design to see the varietal differences.

\section{Results and discussions}

\subsection{Soil analysis}

The detailed soil profile data showed that higher yield was highly correlated with higher soil organic carbon, organic matter, available (Phosphorus, Potassium and Calcium), and exchangeable cation percentages which helped reach a higher yield (Table 1).

Table 1a: Soil Physical and chemical properties determined in study

\begin{tabular}{|c|c|c|c|c|c|c|c|c|c|c|}
\hline \multirow[t]{2}{*}{ Sample } & \multicolumn{3}{|c|}{ percent } & \multirow{2}{*}{$\begin{array}{c}\text { Field } \\
\text { capacity } \\
(\%)\end{array}$} & \multirow{2}{*}{$\begin{array}{c}\text { Available } \\
\mathbf{P} \\
\left(\mathrm{mg} \mathrm{kg}^{-1}\right)\end{array}$} & \multicolumn{2}{|c|}{$\begin{array}{l}\text { NH4OAc extract } \\
\left(\mathrm{mg} \mathrm{kg}^{-1}\right)\end{array}$} & \multirow{2}{*}{$\begin{array}{c}\begin{array}{c}\text { DTPA } \\
\text { extract } \\
\left(\mathbf{m g ~ k g}^{-1}\right)\end{array} \\
\text { Fe }\end{array}$} & \multirow{2}{*}{$\begin{array}{c}1: 5 \\
\mathrm{H}_{2} \mathrm{O}\end{array}$} & \multirow[t]{2}{*}{$\begin{array}{l}\text { Soil } \\
\text { Texture }\end{array}$} \\
\hline & OM & $\mathrm{OC}$ & CEC & & & $\mathbf{K}$ & $\mathrm{Ca}$ & & & \\
\hline $0-5 \mathrm{~cm}$ & 1.88 & 0.78 & 3.40 & 14.80 & 131.49 & 182.12 & 161.44 & 119.34 & 5.05 & $\begin{array}{l}\text { Sandy clay } \\
\text { loam }\end{array}$ \\
\hline $5-15 \mathrm{~cm}$ & 1.85 & 0.81 & 3.00 & 14.60 & 120.35 & 165.59 & 181.52 & 137.92 & 5.24 & $\begin{array}{l}\text { Sandy clay } \\
\text { loam }\end{array}$ \\
\hline $15-25 \mathrm{~cm}$ & 1.70 & 0.77 & 3.00 & 12.80 & 107.32 & 156.00 & 198.52 & 124.34 & 5.00 & $\begin{array}{l}\text { Sandy clay } \\
\text { loam }\end{array}$ \\
\hline $25-35 \mathrm{~cm}$ & 1.69 & 0.77 & 3.00 & 12.40 & 105.23 & 152.20 & 195.57 & 134.20 & 5.11 & $\begin{array}{l}\text { Sandy clay } \\
\text { loam }\end{array}$ \\
\hline $35-50 \mathrm{~cm}$ & 1.69 & 0.76 & 3.00 & 12.00 & 103.45 & 150.10 & 188.80 & 130.00 & 5.01 & $\begin{array}{l}\text { Sandy clay } \\
\text { loam }\end{array}$ \\
\hline $\begin{array}{l}50-65 \\
\mathrm{~cm}\end{array}$ & 1.69 & 0.76 & 2.98 & 12.00 & 102.20 & 150.00 & 190.90 & 128.23 & 5.00 & $\begin{array}{l}\text { Sandy clay } \\
\text { loam }\end{array}$ \\
\hline Average & 1.75 & 0.78 & 3.06 & 13.01 & 111.67 & 159.34 & 186.13 & 129.00 & 5.06 & \\
\hline
\end{tabular}

\subsection{Weather conditions}

The detailed weather data showed that weather conditions had no visible variations across the cropping season 20172018. The maximum and minimum temperatures ranged between 25 and $38^{\circ} \mathrm{C}$ and from 20 to $22^{\circ} \mathrm{C}$. Solar radiation ranged from 10.2 to $20 \mathrm{MJ} \mathrm{m}^{-2} \mathrm{~d}^{-1}$. Rainfall range was 20$980 \mathrm{~mm}$ from July to December months and the highest rainfall was in November to mid-December. After that, January was the second most rainfall month having about 
Simulating upland rice yield at diverse temperatures using DSSAT4.7-CERES-Rice crop model under changing climatic conditions

$700 \mathrm{~mm}$ of rainfall. Linquist et al. (2005) noted that in some cases, although the total annual amount of rainfall shows not much difference, the differences in its distribution can lead to risk of drought or flood, having impact on upland rice yields. Optimum temperature required for upland rice growth is $25^{\circ} \mathrm{C}$ to $35^{\circ} \mathrm{C}$ (Yoshida, 1978) and for anthesis period it is between $30^{\circ} \mathrm{C}-33^{\circ} \mathrm{C}$ (Surajit et al., 1981). A schematic representation of these critical parameters is presented in Fig. 1a and 1b.

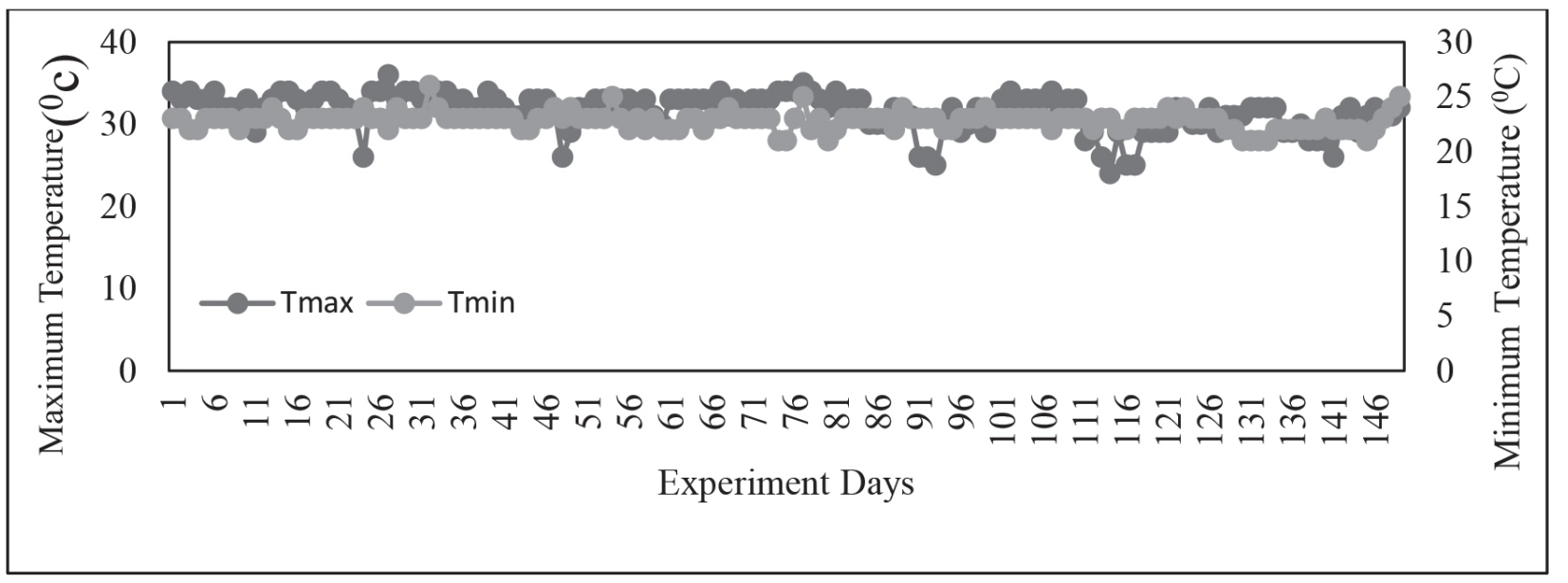

Fig. 1 (a): Mean daily maximum and minimum temperatures used in DSSAT

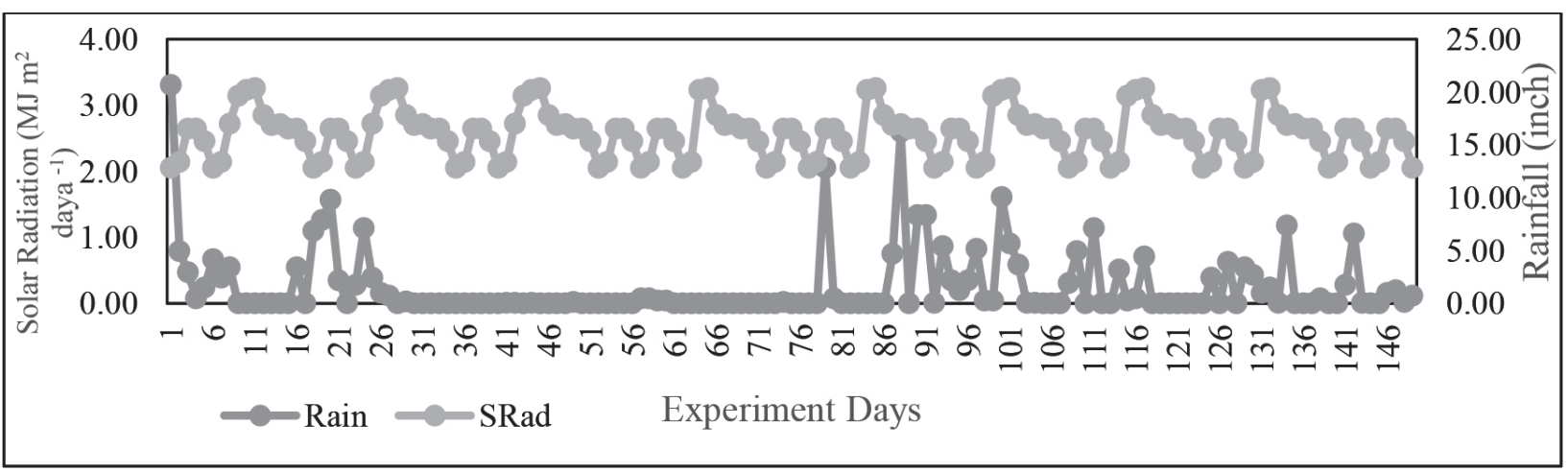

Fig. 1 (b): Mean daily solar radiation and rainfall used in DSSAT

\subsection{Model calibration for estimating genetic coefficients}

Based on experiments, the parameter calibration was done iteratively until a close match between simulated and observed phenology and yield was obtained. Out of 25 genotypes from DSSAT model, four were found to be similar to the genotypes under investigation. Dawk Payawm, Mai Tahk comparatively matched with Basmati 385, Bow Leb Nahng, Dawk Kha-50 with CL448, Nahng Kian with Basmati-515 Rice and Dawk Kahm matched with KS-282 Rice. Results showed juvenile or basic vegetative stage $(\mathrm{P} 1)$, critical photoperiod $(\mathrm{P} 2 \mathrm{O})$, phasic development phase (P2R) and time period (P5) for grain filling were the same for all the genotypes. But Potential spikelet number of coefficient $(\mathrm{G} 1)$ was higher for most

of the genotypes namely Dawk Pa-yawm (79.9), Mai Tahk (79.8), Bow Leb Nahng (79.1), Dawk Kha 50 (78.8) and very low for Dawk Kahm (52.3) compared to others. Highest single grain weight (G2) was observed from the genotypes Dawk Pa-yawm and Dawk Kha 50 (0.0300) and lowest for Dawk Kahm (0.0200). The highest tillering coefficient (G3) was noted for Dawk Kahm (0.89) and the lowest was for Bow Leb Nahng (0.33). Moreover, the highest temperature tolerance coefficient (G4) was observed for Bow Leb Nahng (1.09) and the lowest for Dawk Pa-yawm (0.82). All the calibrated genetic coefficients are shown in Table 2. 
Table 2: Calibrated Genetic coefficient values [P1 (Time period or basic vegetative phase), P2O (Critical photoperiod), P2R (Photoperiodism coefficients), P5 (Grain filling duration coefficient), G1 (Spikelet number coefficient), G2 (Single grain weight), G3 (Tillering coefficients), and G4 (Temperature tolerance coefficient) for 5 Thai upland rice genotypes

\begin{tabular}{|c|c|c|c|c|c|c|c|c|c|}
\hline \multirow{2}{*}{ Genotypes } & \multirow{2}{*}{$\begin{array}{l}\text { Chosen } \\
\text { genotypes }\end{array}$} & \multicolumn{8}{|c|}{ Genetic coefficient values } \\
\hline & & $\mathbf{P 1}$ & $\mathrm{P} 2 \mathrm{O}$ & $\mathbf{P} 2 \mathbf{R}$ & P5 & G1 & G2 & G3 & G4 \\
\hline Bow Leb Nahng & CL448 & 126.0 & 10.9 & 250.0 & 500.0 & 79.1 & 0.029 & 0.33 & 1.09 \\
\hline Nahng Kian & Basmati-515 & 126.0 & 10.9 & 250.0 & 500.0 & 52.3 & 0.020 & 0.89 & 0.95 \\
\hline Dawk Kha-50 & CL448 & 126.0 & 10.9 & 250.0 & 500.0 & 78.8 & 0.030 & 0.61 & 0.90 \\
\hline Mai Tahk & Basmati 385 & 126.0 & 10.9 & 250.0 & 500.0 & 79.8 & 0.024 & 0.37 & 0.98 \\
\hline Dawk Pa-yawm & Basmati 385 & 126.0 & 10.9 & 250.0 & 500.0 & 79.9 & 0.030 & 0.61 & 0.82 \\
\hline
\end{tabular}

\subsection{Yield performance}

ANOVA result (Table 3) for phenological traits using least significant differences (LSD) test (with thresholds $\mathrm{P}<0.05$ and $\mathrm{P}<0.01$ ) revealed that some traits i.e., grain yield, tops weight, flowering, and maturity date were affected by temperatures and had highly significant difference with temperatures for both cropping years. Non-significant difference for tiller number, leaf area index with harvest index occurred possibly due to the optimum input at the early stage. It was also found that grain yield at each treatment reduced with delay in planting date, whereas some of the phenological traits had highly significant variation by genotype.

Table 3: Mean squares from analysis of variance for 5 Thai upland rice genotypes

\begin{tabular}{|c|c|c|c|c|c|c|c|c|}
\hline \multirow[b]{2}{*}{ Source } & \multirow[b]{2}{*}{ df } & \multicolumn{7}{|c|}{ Mean Squares } \\
\hline & & TN & TW & LAI & HI & GY & FD & MD \\
\hline Replication & 2 & 3.82 & 6897576 & 0.00054 & 0.00033 & 1123827 & 279.20 & 33.76 \\
\hline Temperature $(\mathrm{T})$ & 2 & 8.96 & $7514889^{* *}$ & 0.0017 & 0.00050 & $21101974^{* *}$ & $1483.40^{* *}$ & $3.29^{* *}$ \\
\hline Error (a) & 4 & 3.46 & $1909466^{* *}$ & 0.0003 & 0.00034 & $895471^{* *}$ & $247.000^{* *}$ & $18.00^{* *}$ \\
\hline Genotypes (G) & 4 & $26360 * *$ & $1412618^{* *}$ & $0.0310^{* *}$ & $0.17674^{* *}$ & $8567099^{* *}$ & 2.00 & $9.48^{* *}$ \\
\hline $\mathrm{T} \times \mathrm{G}$ & 8 & 2.20 & 265645 & 0.0017 & 0.00008 & $210410^{* *}$ & $5.01^{* *}$ & $1.844^{* *}$ \\
\hline Error (b) & 24 & 5.99 & 113482 & 0.0009 & 0.00012 & 61252 & 0.82 & 1.94 \\
\hline $\mathrm{CV} \%(\mathrm{a})$ & & 3.41 & 16.67 & 1.04 & 3.06 & 16.51 & 17.28 & 3.87 \\
\hline $\mathrm{CV} \%(\mathrm{~b})$ & & 4.49 & 4.06 & 1.71 & 1.80 & 4.32 & 0.99 & 1.27 \\
\hline
\end{tabular}

Here, $\mathrm{TN}=$ Tillers Number, TW= Tops Weight, LAI= Leaf Area Index, HI= Harvest Index, GY= Grain Yield, FD= Flowering Date and MD= Maturity Date. $*=$ significant at $5 \%$ level; ** = significant at $1 \%$ level

\subsection{Mean comparison for phenotypic parameters}

Dawk Kahm genotype had highest tiller number, with very low leaf area index, harvest index and grain yield both cropping seasons (Table 4). It seems that Dawk kahm was highly affected for all the temperature stages and showed temperature sensitive genotype. Besides, Bow Leb Nahng genotype had lowest tiller number, with highest tops weight, leaf area index, highest maturity days and grain yield in 2017/2018 cropping season. The finding was very much similar with (Kumar et al., 2014). The simulated phenology and yield were found in agreement with observed data suggesting that calibrated CERES rice crop model can be used suitably with observed soil, crop management and weather parameters. 
Simulating upland rice yield at diverse temperatures using DSSAT4.7-CERES-Rice crop model under changing climatic conditions

Table 4: Mean comparison of traits for the selected Thai upland rice genotypes

\begin{tabular}{lccccccc}
\hline \multirow{2}{*}{\multicolumn{1}{c}{ Genotypes }} & \multicolumn{7}{c}{ Traits } \\
\cline { 2 - 7 } & TN (no) & TW (gm) & LAI & HI & GY (kgha-1 $)$ & FD (day) & MD (day) \\
\hline Bow Leb Nahng & 23.33 & 8589.30 & 1.83 & 0.65 & 6231.80 & 91 & 111 \\
Dawk Kahm & 150.74 & 7610.10 & 1.69 & 0.35 & 3991.00 & 92 & 109 \\
Dawk Kha & 37.89 & 8313.40 & 1.73 & 0.69 & 6133.20 & 91 & 109 \\
Mai Tahk & 24.67 & 8404.00 & 1.69 & 0.62 & 6235.00 & 91 & 109 \\
Dawk Pa-yawm & 36.33 & 8589.30 & 1.69 & 0.69 & 6067.80 & 91 & 109 \\
LSD $_{0.05}$ & 2.38 & 327.75 & 0.03 & 0.010 & 240.79 & - & 1.35 \\
LSD $_{0.01}$ & 3.23 & 444.16 & 0.04 & 0.014 & 326.31 & - & 1.84 \\
\hline
\end{tabular}

Tiller Number (TN), Top Weight (TW), Leaf Area Index (LAI), Harvest Index (HI), Grain Yield (GY), Flowering Date (FD) and Maturity Date (MD)

\subsection{Simulated effect of temperature on $G Y$}

After calibration of the model, a comparison was made between simulated and observed grain yield at $28^{\circ} \mathrm{C}, 30^{\circ} \mathrm{C}$ and $32^{\circ} \mathrm{C}$ temperature stages (Table 5). Results showed in 2017-2018, Bow Leb Nahng was the high yielding genotype due to increasing simulated grain yield and performed best at the moderate $28^{\circ} \mathrm{C}$ temperature. At $32^{\circ} \mathrm{C}$ temperature, a large variation for all the genotypes by decreasing grain yield as the maximum temperature increased. Highest reduction in simulated grain yield was recorded for Dawk Kahm genotype (3189 kgha-1 at $28^{\circ} \mathrm{C}, 3252 \mathrm{kgha}^{-1}$ at $30^{\circ} \mathrm{C}$ and $3194 \mathrm{kgha}^{-1}$ at $32^{\circ} \mathrm{C}$ ) with best performance at the high temperature $30^{\circ} \mathrm{C}$ stage in $2017-2018$ cropping season. Similar finding was reported by Shamim et al., 2010 and Singh et al., 2014. Paradoxically Bow Leb Nahng (6669 kgha ${ }^{-1}$ ) and Dawk Pa-yawm (6239 kgha-1) showed increased simulated grain yield while they were the best performing genotypes with the high temperature $32^{\circ} \mathrm{C}$. As these two genotypes performed highest maturity in their life cycle. Similar finding was shown by Peng et al. (2004). The simulated grain yield of upland rice ranged between 3189-6711 kgha ${ }^{-1}$ respectively. The finding was very much like that of Singh et al. (2014).

Table 5: Measured and simulated grain yield of Thai upland rice genotypes at varying temperature levels with the DSSAT-CERES-Rice model

\begin{tabular}{lcccccc}
\hline \multirow{2}{*}{ Genotypres } & \multicolumn{2}{c}{$\mathbf{2 8}^{\circ} \mathbf{C}$} & \multicolumn{2}{c}{$\mathbf{3 0}^{\circ} \mathbf{C}$} & \multicolumn{2}{c}{$\mathbf{3 2}^{\circ} \mathbf{C}$} \\
\cline { 2 - 7 } & Measured & Simulated & Measured & Simulated & Measured & Simulated \\
\hline Bow Leb Nahng & 7762 & 6711 & 5857 & 6667 & 5074 & 6669 \\
Dawk Kahm & 4829 & 3189 & 3808 & 3252 & 3335 & 3194 \\
Dawk Kha & 7431 & 6303 & 5947 & 6224 & 5021 & 6239 \\
Mai Tahk & 7732 & 5804 & 5920 & 5677 & 5055 & 5696 \\
Dawk Pa -yawm & 7323 & 6303 & 5983 & 6224 & 4897 & 6239 \\
\hline
\end{tabular}

Grain yield decreased with increase in temperature at $28^{\circ} \mathrm{C}, 30^{\circ} \mathrm{C}$ and $32^{\circ} \mathrm{C}$ (Maniruzzaman et al., 2018). This indicated that upland rice production might decrease in the future if climate smart practices are not adopted. Grain yield reduction was higher with short and medium growth duration rice genotypes compared to long duration Bow Leb Nahng, Mai Tahk and Dawk Pa-yawm. In general, the effect of increased temperature would be negative because of increased respiration (Penning de Vries et al., 1993) and shortened vegetative and grain filling period.
In Sri Lanka by using the DSSAT-CERES-Rice model estimated for every degree rise in temperature near about 5\% yield reduction occurred reported by Dias et al., (2016).

\section{Conclusion}

The DSSAT-CERES-Rice crop simulation model was well validated and showed reliability of simulations with different temperatures for phenology and yield attributes of selected upland rice genotypes. Our study assessed the DSSAT-CERES-Rice model in a split plot experiment 
including two factors; viz the genotypes (5 Thai upland rice genotypes) and another one of different temperatures (3 levels) to identify the variations of grain yield in southern Thailand under changing climatic conditions. The findings revealed that increase in temperature had negative effect on most of the genotypes. Thus, CERES-Rice model could be effectively used as a tool to simulate the grain yield of upland rice genotypes with the climate changing parameters like temperature stages.

\section{Conflict of Interest}

Authors declare that they have no conflict of interest.

\section{Ethical Compliance Statement}

NA

\section{Author Contribution}

Conceptualization \& Initial Draft: SSI, AKH; Critical review and finalization: SSI, AKH

\section{References}

1. Araus JL and GA Slafer. 2001. Crop Stress Management and Global Climate Change. CABI 875 Massachusetts Avenue, Cambridge, MA 02139 USA.

2. Chen C, E Wang and Q Yu. 2010. Modeling the effects of climate variability and water management on crop water productivity and water balance in the North China Plain. Agricultural Water Management. 97(8): 1175-1184. Available from: https://doi. org/10.1016/ j. ag wat. 2008.11.012.

3. Cruz RV, H Harasawa, M Lai, S Wu, Y Anokhin, B Punsalmaa, Y Honda, M Jafari, C Li and HN Ninh. 2007. Asia Climate change 2007: Impacts, Adaptation, and vulnerability. Contribution of Working Group II to the Fourth Assessment Report of the International Panel on Climate Change. Parry ML, Canziani OF, Palutikof JP, Van der Linden PJ, Hanson CE Eds., Cambridge University Press, Cambridge, UK, 469506.

4. De Datta SK, AC Tauro and SN Balaoing. 1998. Effect of plant type and nitrogen level on the growth characteristics and grain yield of indicate rice in the tropics. Agronomy Journal 60:643-647.

5. Dias MPNM, CM Navaratne, KDN Weerasinghe and RHAN Hettiarachachi. 2016. Application of DSSAT Crop Simulation Model to Identify the Changes of Rice Growth and Yield in Nilwala River Basin for
Mid-centuries under Changing Climatic Conditions. Procedia. Food. Science 6: 159-163.

6. FAO. 2019. Report of the International Rice Commission, Twenty Session. Bangkok, Thailand, 23-26 July 2009. FAO, Rome, 46 p.

7. Goyal V, RS Malik and BS Jhorar. 2012. Modeling groundwater recharge from the lined farm canal under shallow water table condition. Indian Journal of Agricultural Research 46(3): 217-225.

8. IPCC. 2013. Summary for Policymakers. In: Stocker TF, Qin D, Plattner GK, Tignor M, Allen SK, BoschungJ, Nauels A, Xia Y, Bex V and Midgley PM, eds. Jalota SK. 2009. Integrated effect of transplanting date, cultivar and irrigation on yield, water saving and water productivity of rice (Oryza sativa L.) in Indian Punjab: field and simulation study. Agricultural Water Management 96: 1096-1104.

9. Jat SR, IJ Gulati, ML Soni, A Kumawat, ND Yadava, V Nangia, M Glazirina, and VS Rathor. 2017. Water productivity and yield analysis of groundnut using Crop Syst simulation model in hyper arid partially irrigated zone of Rajasthan. Legume Research 40(4): 1-6. Available from: https://doi.org/10.18805/ lr.v40i04.9003.

10. Kiniry J, R Williams, J Vanderlip, D Atwood, W Muuliken, H Cox and W Weibold. 1997. Evaluation of two maize models for nine U.S. locations. Agronomy Journal 89: 421-426.

11. Krishnan, P., Ramakrishnan, B., Reddy, k. R., and Reddy, V. R. 2011. High-Temperature Effects on Rice Growth, Yield, and Grain Quality. Journal of Advances in Agronomy. 111(2011): 1-122. DOI: 10.1016/B978-012-387689-8.00004-7.

12. Kumar B., P K Singh, K K Singh, A K Baxla, S C Bhan, and L S Rathore. 2014. Crop yield prediction using CERES-Rice vs 4.5 model for the climate variability of different agroclimatic zone of south and north-west plane zone of Bihar (India). Mausam. 65(4): 529-538.

13. Lizaso J, K Boote, J Jones, C Porter, L Echarte, M Westgate and G. Sonohat. 2011. CSM-IXIM: A New Rice Simulation Model for DSSAT Version 4.5. Biometry, Modelling and Statistics. Agronomy 
Simulating upland rice yield at diverse temperatures using DSSAT4.7-CERES-Rice crop model under changing climatic conditions

Journal 103: 766-779. Available from: http://dx.doi. org/10.2134/agronj 2010. 0423.

14. Linquist BA and P Sengxua. 2005. Nutrient management for low land paddy rice in Lao PDR. National Rice Research Program (NRRP), and LaoIRRI project, National Agriculture and Forestry Research Institute (NAFRI). (in Lao language).

15. Lone BA, S Qayoom, RARS Rajouri and N Panotra. 2016. Validation for Growth and Productivity of Various Rice Cultivars under Temperate Conditions of Kashmir Valley Using CERESRice Model. Proceedings of the $10^{\text {th }}$ INDIA Com; INDIACom-2016; IEEE Conference ID: 37465 , 2016, 3rd International Conference on "Computing for Sustainable Global Development", $16^{\text {th }}-18^{\text {th }}$ March 2016 Bharati Vidyapeeth's Institute of Computer Applications and Management (BVICAM), New Delhi (INDIA).

16. Maniruzzaman M, M B Hossain, JC Biswas and MM Haque. 2018. Effect of Elevated Air Temperature and carbon Di oxide levels on Dry Season Irrigated Rice Productivity in Bangladesh. American Journal of Plant Science 2018(9): 1557-1576.

17. Mendiburu FD and R Simon. 2007. Agricolae-a free statistical library for agricultural research. Ames, IA: Iowa State University.

18. Nayak A K, M Shahid, AD Nayak, B Dhal, KC Moharana, B Mondal, R Tripathi, SD Mohapatra, P Bhattacharyya, N Jambhulkar, AK Shukla, N Fitton, P Smith and H Pathak. 2019. Assessment of ecosystem services of rice farms in eastern India. Ecological Processes (2019):1-16. https://doi.org/10.1186/s13717019-0189-1.

19. Peng S, J Huang and J E Sheehy. 2004. "Rice yield decline with higher night temperature from global warming," in Rice Integrated Crop Management: Towards a Rice check System in the Philippines, ED. Redona AP. Castro, and GP. Llanto, Eds pp. 46-56, Phil Rice, Nueva Ecija, Philippines.

20. Penning De Vries FWT, DM Jansen, Ten Bergehfm and A Bakema. 1993. Simulation of Ecophysiological process of Growth in Several Annual Crops. PUDOC, Wageningen, the Netherlands: 271.
21. Reidsma P, F Wert, OA Lansink and R Leemans. 2010. Adaptation to climate change and climate variability in European agriculture: The importance of farm level responses. European Journal Agronomy 32(1): 91 -102.

22. Rezzoug W, B Gabriflle, A Suleiman and K Benabdell. 2008. Application and evaluation of the DSSAT-wheat in the Tiaret region of Algeria. African Journal of Agricultural Research 3(4): 284-296.

23. Shamin M, RH Patel, V Pandey and MM Lunagaria. 2010. Sensitivity of CERES-Rice model to different environmental parameters on the productivity of aromatic rice in middle Gujarat. International Journal of Agricultural Technology 12(2): 213-216.

24. Soler C, P Snetelhas and G Hoogenboom. 2007. Application of the CSM-CERES-Maize model for planting date evaluation and yield forecasting for maize grown off-season in a subtropical environment. European Journal of Agronomy 27(2-4): 165-177. Available from: http://dx.doi.org/10.1016/j.eja.2007.03.002.

25. Surajit K and D Datta. 1981. Principles and Practices of rice production. A Wiley Inter science Publication New York, Chichester, Brisbane, Toronto, Singapore.

26. Tazhibayeva K, J Felkner and R Townsend. 2009. Impact change on rice production in Thailand. American Economic Review 99(2): 205-210. DOI:10.1257/ aer.99.2.205

27. Wang J, R Mendelsohn, A Dinar, J Huang, S Rozelle and L Zhang. 2009. The Impact of Climate Change on China's Agriculture. Agricultural Economy 40: 323337. Available from: https://doi.org/10.1111/j.15740862.2009.00379.x

28. Wilkens PW, G Hoogenboom. CH Porter, JW Jones and O Uryasev. 2004. Data management and Analysis Tools, Volume 2. DSSAT v4 (A Decision Support System for Agrotechnology Transfer).

29. Willmott CJ. 1982. Some comments on the evaluation of model performance. Bulletin of the American Meteorological Society 63: 1309-1369.

30. Yoshida S. 1978. Tropical climate and its influence on rice [periodicity, productivity, and stability]. IRRI, Los Baños, Philippines. IRRI Res. Paper Series 20. 